\title{
Acute and chronic toxicological studies of the Brazilian phytopharmaceutical product Ierobina ${ }^{\circledR}$
}

\author{
Carlos A. Tagliati, ${ }^{*, 1}$ Renata P. Silva, ${ }^{1}$ Cássia A. O. Féres, ${ }^{1}$ Rodrigo. M. Jorge, ${ }^{1,2}$ Orivaldo A. \\ Rocha, ${ }^{3}$ Fernão C. Braga ${ }^{3}$ \\ ${ }^{1}$ Departamento de Análises Clínicas e Toxicológicas, Faculdade de Farmácia, Universidade Federal de Minas \\ Gerais, 31270-901 Belo Horizonte-MG, Brazil, \\ ${ }^{2}$ Departamento de Patologia Geral, Instituto de Ciências Biológicas, Universidade Federal de Minas Gerais, \\ 31270-901 Belo Horizonte-MG, Brazil, \\ ${ }^{3}$ Departamento de Produtos Farmacêuticos, Faculdade de Farmácia, Universidade Federal de Minas Gerais, \\ 31270-901 Belo Horizonte-MG, Brasil
}

\begin{abstract}
RESUMO: "Estudos de toxicidade aguda e crônica do produto fitoterápico brasileiro Ierobina $^{\circledR}{ }^{\circledR}$. A Ierobina ${ }^{\circledR}$ é um produto utilizado popularmente, no Brasil, para tratamento de dispepsia, na dose de $280 \mathrm{mg} / \mathrm{kg} / \mathrm{dia}$. Apesar de seu largo uso nos últimos 75 anos, recentemente foi comprovada sua eficácia em animais; porém, nenhuma avaliação de seu perfil toxicológico foi realizada. O objetivo do presente estudo foi avaliar a toxicidade aguda (doses únicas de 2100 $\mathrm{mg} / \mathrm{kg}, 6300 \mathrm{mg} / \mathrm{kg}$ ou $12600 \mathrm{mg} / \mathrm{kg}$ ), em camundongos, e crônica (doses de $2800 \mathrm{mg} / \mathrm{kg}$ ou 5600 $\mathrm{mg} / \mathrm{kg}$, por 180 dias), em ratos, após administração per os de Ierobina ${ }^{\circledR}$. No teste de toxicidade aguda, as doses administradas não produziram nenhuma mortalidade e os sinais observados foram todos reversíveis. No teste de toxicidade crônica, não foram verificadas diferenças significativas nas análises hematológicas, macroscópicas e microscópicas. Nos exames de bioquímica sérica, diferença significativa foi observada somente na avaliação da alanina transaminase, aspartato transaminase e creatinina, porém, sem importância clínica. Assim, considerando os resultados obtidos e o fato de ser a Ierobina ${ }^{\circledR}$ um produto comercializado há décadas, sem qualquer notificação de casos de toxicidade, podemos concluir que o produto parece ser de segurança adequada para uso humano.
\end{abstract}

Unitermos: Ierobina ${ }^{\circledR}$, toxicidade aguda e crônica, produto fitofarmacêutico.

\begin{abstract}
Ierobina ${ }^{\circledR}$ is a Brazilian phytopharmaceutical product employed for the treatment of dyspepsia $(280 \mathrm{mg} / \mathrm{kg} /$ day $)$. Despite its widespread use in the country for over 75 years, only recently its therapeutic efficacy has been attested in animals; however, no toxicological investigations have been carried out for the product to date. In this paper we evaluated the acute toxicity of Ierobina ${ }^{\circledR}$ administrated by gavage in mice (single doses of $2100 \mathrm{mg} / \mathrm{kg}, 6300 \mathrm{mg} /$ $\mathrm{kg}$ and $12600 \mathrm{mg} / \mathrm{kg}$ ), along with its chronic effects in rats, after product administration per os daily, at the doses of $2800 \mathrm{mg} / \mathrm{kg}$ and $5600 \mathrm{mg} / \mathrm{kg}$, for 180 days. The product had low acute toxicity; all observed alterations were reversible and no animal died during the experiments. In chronic toxicological studies, Ierobina ${ }^{\circledR}$ administration for 180 days did not cause any changes in hematological and biochemical parameters, with the exception of decreasing the levels of alanine transaminase, aspartate transaminase and creatinine. However, histological evaluation of kidney, liver and other selected organs showed normal architecture, suggesting no morphological disturbances. Hence, considering the obtained results and the fact that Ierobina ${ }^{\circledR}$ has been commercialized for decades in Brazil, without any notified case of toxicity, it seems that the product is safe for human use.
\end{abstract}

Keywords: Ierobina ${ }^{\circledR}$, acute and chronic toxicity, phytopharmaceutical product.

\section{INTRODUCTION}

The research on medicinal plants has experienced a huge increase in the last years and some traditional species have been the starting point for the discovery of many important drugs. According to WHO, approximately 20,000 plant species are employed for medicinal purposes around the world (Phillipson, 1994).
Brazil has the richest biota among the megadiversity countries, possessing at least 10 to $20 \%$ of all planet species (Mittermerier et al., 1997). It is believed that less than $10 \%$ of the estimated 55,000 Brazilian plants have been submitted to chemical and pharmacological studies (Gottlieb and Mors, 1980). Some herbal products have been developed from these bioresources, most of them based on traditionally used species. According 
to the Brazilian legislation, phytopharmaceutical products based on traditional plants must also have their pharmacological efficacy and absence of toxicity attested for commercialization purposes (Brasil, 2004; Carvalho et al., 2008). Despite of that, several herbal products are launched in the Brazilian market without following these guidelines.

The treatment of functional gastrointestinal disorders is one of the domains of herbal therapy (Saller et al., 2001). Several phytopharmaceutical products are available for treating dyspepsia (Saller et al., 2002; Gundermann et al., 2003), a condition comprising a complex of symptoms in the upper gastrointestinal tract which includes, in addition to epigastric pain or discomfort, symptoms such as heartburn, acid regurgitation, excessive burping or belching, a feeling of slow digestion, early satiety, nausea and bloating (Talley, 2001; Hunt et al., 2002).

Most of the symptoms from dyspepsia are short lasting and of medium severity, being usually selfmanaged (Johannessen et al., 1993). Both in Europe and in the USA, less than half of the patients suffering from dyspepsia look for medical assistance (Lydeard and Jones, 1989; Talley et al., 1992). The extensive use of herbal drugs to treat this condition is based on the incorrect perception that natural products are always safe (Gesler, 1992). Nevertheless, adverse effects associated to their use for treating non-ulcer dyspepsia have been reported (Thompson Coon and Ernst, 2002).

Ierobina $^{\circledR}$ is a Brazilian phytopharmaceutical product indicated for the treatment of dyspepsia. The formulation contains the fluid extracts of Solanum paniculatum L. (Solanaceae), Remijia ferruginea D.C. (Rubiaceae), Jacaranda caroba D.C. (Bignoniaceae) and Erythraea centaurium (L.) Borkh. (Gentianaceae). Except for E. centaurium, a European species, the other plants occur in Brazil and are popularly employed for treating gastrointestinal disorders, including dyspepsia, among several other medicinal uses (Braga et al., 2003; Botion et al., 2005). There is no report on the traditional use of these plants in association; nevertheless, Ierobina $^{\circledR}$ has a widespread popular utilization in Brazil for treating dyspepsia associated with the intake of high-fat meals. It should be reminded that several herbal drugs are constituted by a mixture of plants and their cumulative effect increases preparation efficacy in curing the diseases (Manoamani et al., 1995).

Although Ierobina ${ }^{\circledR}$ has been commercialized for over 75 years in the country, only recently its efficacy as a dyspeptic agent has been attested in animals (Botion et al., 2005). On the other hand, no toxicological investigations have been carried out for the product to date. Therefore, the main goal of the present study was to assay the acute and chronic toxicity of Ierobina ${ }^{\circledR}$ in mice and rats, respectively, after its administration per os.

\section{MATERIAL AND METHODS}

\section{Phytopharmaceutical product Ierobina}

Ierobina $^{\circledR}$, control no. 8324, was furnished by Laboratório Belfar (Belo Horizonte, Brazil). It is a solution, commercialized in $10 \mathrm{~mL}$ flacons, containing the fluid extracts of Solanum paniculatum leaves $(0.8$ $\mathrm{mL})$, Remijia ferruginea leaves $(0.8 \mathrm{~mL})$, Erythraea centaurium leaves $(0.2 \mathrm{~mL})$ and Jacaranda caroba aerial parts $(0.2 \mathrm{~mL})$.

\section{Animals}

Male and female Wistar rats $(220 \pm 20 \mathrm{~g})$ and Swiss mice $(30 \pm 5 \mathrm{~g})$, provided by the Animal House of Faculdade de Farmácia of the Universidade Federal de Minas Gerais (UFMG), Belo Horizonte, Minas Gerais, Brazil, were used. The animals were allowed to acclimatize in the experimental room for 1 week before the experiments. The animals were kept at controlled temperature $\left(23 \pm 2{ }^{\circ} \mathrm{C}\right)$ and humidity (50\%-60\%) conditions in a 12-hour light/dark cycle (7:00-19:00). The experimental protocols have been approved by the Ethics Committee on Animal Experimentation (CETEA) of UFMG (protocol no 036/04).

\section{Acute toxicity studies}

Each of the three doses of Ierobina ${ }^{\circledR}(2100 \mathrm{mg} /$ $\mathrm{kg}, 6300 \mathrm{mg} / \mathrm{kg}$ and $12600 \mathrm{mg} / \mathrm{kg}$ ) was administered by gavage as a single dose to 10 mice ( 5 males and 5 females). Food and water were available ad libitum, except for a 4 hours fastening period before product administration. The general behavior of animals was monitored for 5, 15, 60, 120, $240 \mathrm{~min}$ and $24 \mathrm{~h}$ after treatment. The mice were further observed twice a day for up to 14 days following treatment for any signs of toxicity and deaths.

\section{Chronic toxicity studies}

The animals were divided into three groups of 16 rats each ( 8 males and 8 females). Ierobina ${ }^{\circledR}$ was administered by gavage, daily for 180 days at doses of $2800 \mathrm{mg} / \mathrm{kg}$ and $5600 \mathrm{mg} / \mathrm{kg}$. Control group (16 animals) was treated with saline. Physiological responses and behavior were evaluated daily and the body weight changes, food and water consumption were recorded weekly (OECD, 1981). At the end of the period, the animals were fasted for $12 \mathrm{~h}$ and killed by decapitation. Blood samples were colleted into heparinized and dry non-heparinized centrifuge tubes. Blood analysis (hematology and chemistry) were carried out.

The heparinezed samples were employed for the determination of hematological parameters (total red blood cells, leukocyte and platelet counts, hematocrit 
and hemoglobin). The non-heparinized blood was allowed to coagulate before being centrifuged and the serum was separated. The serum was assayed for uric acid, albumin, total protein, glucose, blood urea nitrogen (BUN), aspartate transaminase (AST), alanine transaminase (ALT), alkaline phosphatases (Alk-P), cholesterol and creatinine. Determinations were carried out using diagnostic kits (Analisa Diagnostica Ltda.). Assays were performed in replicates $(n=8)$ and results are expressed as means \pm S.E.M.

\section{Histopathological studies}

After collecting the blood samples, selected organs (heart, liver, pancreas, kidney, lungs, stomach, spleen and testicles or ovarian) were carefully dissected out and weighed. Portions of these organs were fixed in $10 \%$ neutral formalin solution for the histopathological examinations. Tissues were processed by conventional technique; the paraffin embedded sections of $5 \mu \mathrm{m}$ thickness were prepared and stained with hematoxylin and eosin for microscopic examination.

\section{Statistical analysis}

Statistical significance was determined by one way ANOVA test, followed by Tuckey test and $\mathrm{p}<0.05$ was taken as the criterion of significance.

\section{RESULTS}

\section{Acute toxicity}

There were no deaths after oral administration of single doses of Ierobina ${ }^{\circledR}$, at any dose level $(2100 \mathrm{mg} /$ $\mathrm{kg}, 6300 \mathrm{mg} / \mathrm{kg}$ and $12600 \mathrm{mg} / \mathrm{kg}$ ). The animals showed some behavioral changes in the first day after product administration at the highest dose, including ataxia and slow response to external stimuli; however the changes were absent in subsequent days, suggesting reversibility of effects. No other signs of toxicity were observed in the 14 days of experiment.

\section{Chronic toxicity}

No lethality was registered for any dose up to the maximum of $5600 \mathrm{mg} / \mathrm{kg}$, during the 180 days of Ierobina ${ }^{\circledR}$ administration. There was no evidence of differences for physiological responses and behavior between the control and any of the treated groups, at any time period, as well as for food and water consumption. Moreover, no significant difference in body weight gain and organ weights were noted between the control group and the treated animals at any evaluated doses (Table 1).

The effect of chronic administration of Ierobina ${ }^{\circledR}$ on the hematological parameters is presented in Table
2. No significant changes were observed for the treated group as compared to the control and all parameters remained within normal limits throughout the evaluated period.

The biochemical profiles of the treated and control animals are shown in Table 3. No statistical difference was detected for the assayed parameters, in both doses, as compared to the control group ( $\mathrm{p}<$ $0.05)$.

\section{DISCUSSION}

Despite the fact that Ierobina $^{\circledR}$ has been commercialized in Brazil for decades, only recently its dyspeptic effect was assured. Administration of Ierobina ${ }^{\circledR}$ to high fat-fed rats at the dose of $280 \mathrm{mg} / \mathrm{kg}$ resulted in a $45 \%$ increase of tryacylglycerol-rich lipoprotein uptake, in comparison to the control group receiving high fat diet (Botion et al., 2005). The present investigation demonstrates that the administration per os of Ierobina ${ }^{\circledR}$ to mice and rats do not present toxicological effects.

In the acute toxicological assay, there was no registered death for the mice treated with Ierobina ${ }^{\circledR}$ per os at doses of $2100 \mathrm{mg} / \mathrm{kg}, 6300 \mathrm{mg} / \mathrm{kg}$ and 12600 $\mathrm{mg} / \mathrm{kg}$. It is worth mentioning that such doses are respectively $7.5,22.5$ and 45 times that recommended for human use $(280 \mathrm{mg} / \mathrm{kg})$. Since the pharmacological effect of Ierobina ${ }^{\circledR}$ has been previously demonstrated when given by the oral route to rats, at the dose of 280 $\mathrm{mg} / \mathrm{kg}$ (Botion et al., 2005), it can be concluded that the active compound(s) present in the product devoid of acute oral toxicity. The symptoms of adverse behavior observed in the present study at the highest assayed dose (ataxia and slow response to external stimuli changes) were reversible after $24 \mathrm{~h}$ of product administration.

Toxic effects and obit are uncommon to observe in acute experiments with natural products. This feature can be explained by the intrinsic nature of those products, which contain different compounds, usually in low concentrations, the opposite of synthetic drugs whose toxicity is more prone to appear in acute assays (Féres et al., 2006). The popular perception that natural products do not present toxic effects might be explained within this context, since the recognition of product toxicity is only associated to its use when the effects do manifest immediately after administration.

Therefore, multiple dose studies are necessary to assure the safety of natural products. On the other hand, clinical observations of acute assays are valuable tools to define the doses to be tested in the multiple dose experiments, along with pharmacological studies in animals and in humans (da Silva et al., 2002; Alvarez et al., 2004; Hasumura et al., 2004).

For the chronic study, doses of $2800 \mathrm{mg} / \mathrm{kg}$ and $5600 \mathrm{mg} / \mathrm{kg}$ were employed, respectively 10 and 20 times the human therapeutic dose recommended for treating dyspepsia. For both doses, the body weight gain 
and food consumption were not statistically different in the treated rats as compared to the control group. Changes in body weight have been used as an indicator of adverse effects of drugs and chemicals (Tofovic and Jackson, 1999; Teo et al., 2002; Raza et al., 2002).
Therefore, the results here presented suggest that the chronic administration per os of Ierobina ${ }^{\circledR}$, in doses up to 20 times the therapeutic one, is safe to the studied animals.

A statistical increase in water consumption

Table 1. Body and organ weights (g) of Wistar rats after chronic oral treatment with Ierobina ${ }^{\circledR}$ for 180 days.

\begin{tabular}{|c|c|c|c|}
\hline & \multirow[t]{2}{*}{ Control group (saline) } & \multicolumn{2}{|c|}{ Ierobina $^{(R)}$} \\
\hline & & $2800 \mathrm{mg} / \mathrm{kg}$ & $5600 \mathrm{mg} / \mathrm{kg}$ \\
\hline \multicolumn{4}{|l|}{ Body weight } \\
\hline Male Initial & $253.5 \pm 39.9$ & $256.9 \pm 18.1$ & $269.6 \pm 17.6$ \\
\hline Final & $408.6 \pm 15.6$ & $366.3 \pm 34.7$ & $371.9 \pm 43.4$ \\
\hline Female Initial & $208.7 \pm 17.1$ & $197.2 \pm 8.2$ & $191.0 \pm 10.7$ \\
\hline Final & $246.0 \pm 17.4$ & $264.5 \pm 18.6$ & $230.3 \pm 19.3$ \\
\hline \multicolumn{4}{|l|}{ Organ weight } \\
\hline \multicolumn{4}{|l|}{ Male } \\
\hline Heart & $1.99 \pm 0.31$ & $1.56 \pm 0.30$ & $1.48 \pm 0.19$ \\
\hline Liver & $13.31 \pm 2.36$ & $10.26 \pm 0.78$ & $12.67 \pm 1.84$ \\
\hline Pancreas & $1.80 \pm 0.38$ & $1.32 \pm 0.30$ & $1.40 \pm 0.57$ \\
\hline Kidney & $3.73 \pm 0.45$ & $3.36 \pm 0.40$ & $3.66 \pm 0.35$ \\
\hline Lung & $3.08 \pm 0.52$ & $2.53 \pm 0.42$ & $2.41 \pm 0.34$ \\
\hline Testicles & $7.39 \pm 1.01$ & $6.28 \pm 1.68$ & $6.18 \pm 1.06$ \\
\hline Stomach & $2.57 \pm 0.37$ & $2.09 \pm 0.57$ & $2.56 \pm 0.21$ \\
\hline Spleen & $1.08 \pm 0.19$ & $1.17 \pm 0.16$ & $1.10 \pm 0.17$ \\
\hline \multicolumn{4}{|c|}{ Female } \\
\hline Heart & $1.58 \pm 0.28$ & $1.12 \pm 0.15$ & $1.26 \pm 0.26$ \\
\hline Liver & $8.65 \pm 0.86$ & $8.16 \pm 0.96$ & $9.33 \pm 0.89$ \\
\hline Pancreas & $1.76 \pm 0.60$ & $1.50 \pm 0.27$ & $1.33 \pm 0.65$ \\
\hline Kidney & $2.69 \pm 0.29$ & $2.56 \pm 0.32$ & $3.19 \pm 0.43$ \\
\hline Lung & $2.15 \pm 0.34$ & $2.36 \pm 0.78$ & $2.29 \pm 0.38$ \\
\hline Ovarian & $2.39 \pm 0.51$ & $2.44 \pm 0.61$ & $2.70 \pm 0.97$ \\
\hline Stomach & $2.32 \pm 0.29$ & $1.95 \pm 0.25$ & $2.20 \pm 0.35$ \\
\hline Spleen & $1.12 \pm 0.30$ & $1.00 \pm 0.19$ & $1.26 \pm 0.27$ \\
\hline
\end{tabular}

Data are expressed as mean \pm S.D., $n=8$. No statistical difference between control and Ierobina ${ }^{\circledR}$ groups $(\mathrm{p}<0.05)$.

Table 2. Effect of chronic oral administration of Ierobina ${ }^{\circledR}$ for 180 days on the hematological parameters of Wistar rats.

\begin{tabular}{|c|c|c|c|}
\hline & \multirow[t]{2}{*}{ Control group (saline) } & \multicolumn{2}{|c|}{ Ierobina $^{(R)}$} \\
\hline & & $2800 \mathrm{mg} / \mathrm{kg}$ & $5600 \mathrm{mg} / \mathrm{kg}$ \\
\hline \multicolumn{4}{|l|}{ Male } \\
\hline Global leukocytes & $3.53 \pm 4.12$ & $5.86 \pm 0.45$ & $5.86 \pm 1.30$ \\
\hline Red cells & $6.65 \pm 1.59$ & $6.69 \pm 0.98$ & $5.49 \pm 1.23$ \\
\hline Hemoglobin & $17.9 \pm 4.84$ & $15.43 \pm 1.95$ & $14.55 \pm 1.35$ \\
\hline Hematocrit & $34.75 \pm 9.70$ & $33.78 \pm 5.25$ & $28.46 \pm 5.99$ \\
\hline $\mathrm{MCV}$ & $52.0 \pm 2.94$ & $50.38 \pm 1.85$ & $52.00 \pm 2.45$ \\
\hline $\mathrm{MCH}$ & $26.78 \pm 1.84$ & $23.24 \pm 2.64$ & $27.36 \pm 4.93$ \\
\hline $\mathrm{MCHC}$ & $51.63 \pm 4.90$ & $46.09 \pm 4.92$ & $52.51 \pm 8.17$ \\
\hline Platelets & $486.75 \pm 364.20$ & $643.86 \pm 155.27$ & $596.51 \pm 178.31$ \\
\hline \multicolumn{4}{|l|}{ Female } \\
\hline Global leukocytes & $7.23 \pm 1.27$ & $5.56 \pm 2.82$ & $5.42 \pm 1.10$ \\
\hline Red cells & $5.41 \pm 0.67$ & $7.35 \pm 0.57$ & $5.46 \pm 0.83$ \\
\hline Hemoglobin & $15.78 \pm 1.70$ & $16.61 \pm 0.77$ & $15.30 \pm 1.32$ \\
\hline Hematocrit & $26.85 \pm 3.70$ & $36.41 \pm 2.28$ & $27.70 \pm 4.25$ \\
\hline $\mathrm{MCV}$ & $49.63 \pm 1.41$ & $49.75 \pm 1.91$ & $50.88 \pm 1.73$ \\
\hline $\mathrm{MCH}$ & $29.53 \pm 4.63$ & $22.70 \pm 1.03$ & $28.44 \pm 3.41$ \\
\hline $\mathrm{MCHC}$ & $59.69 \pm 10.10$ & $45.66 \pm 1.71$ & $56.01 \pm 6.69$ \\
\hline Platelets & $490.88 \pm 106.87$ & $688.88 \pm 104.87$ & $510.85 \pm 171.18$ \\
\hline
\end{tabular}

Data are expressed as mean \pm S.D., $n=8$. No statistical difference between control and Ierobina ${ }^{\circledR}$ groups $(\mathrm{p}<0.05)$. 
Table 3. Effect of chronic oral administration of Ierobina ${ }^{\circledR}$ for 180 days on the biochemical parameters of Wistar rats.

\begin{tabular}{lccc} 
& & & \\
& Control group (saline) & Ierobina $^{B}$ \\
\cline { 2 - 3 } & & $2800 \mathrm{mg} / \mathrm{kg}$ & $5600 \mathrm{mg} / \mathrm{kg}$ \\
\hline Male & & $3.80 \pm 0.85$ & $2.58 \pm 0.53$ \\
Uric acid (mg/dl) & $2.11 \pm 1.08$ & $8.14 \pm 0.32$ & $7.73 \pm 2.48$ \\
Total proteins (g/dl) & $7.57 \pm 0.48$ & $4.51 \pm 1.03$ & $4.60 \pm 0.62$ \\
Albumine (g/dl) & $4.16 \pm 0.53$ & $148.95 \pm 36.39$ & $118.84 \pm 52.94$ \\
ALT (units/l) & $190.06 \pm 46.36$ & $205.76 \pm 36.00$ & $161.70 \pm 55.09$ \\
AST (units/l) & $243.84 \pm 61.43$ & $0.46 \pm 0.07$ & $0.39 \pm 0.15$ \\
Creatinine (mg/dl) & $0.66 \pm 0.08$ & $117.94 \pm 30.47$ & $114.57 \pm 39.52$ \\
Cholesterol (mg/dl) & $85.40 \pm 12.90$ & $58.38 \pm 21.04$ & $59.53 \pm 24.36$ \\
Alkaline phosfatase (units/l) & $72.96 \pm 17.94$ & $84.86 \pm 27.64$ \\
Glucose (mg/dl) & $172.89 \pm 63.78$ & $61.12 \pm 7.17$ & $49.14 \pm 14.80$ \\
Urea (mg/dl) & $66.42 \pm 5.24$ & & \\
Female & & $2.89 \pm 0.54$ & $2.68 \pm 0.73$ \\
Uric acid (mg/dl) & $2.04 \pm 1.23$ & $8.72 \pm 0.54$ & $8.89 \pm 0.82$ \\
Total proteins (g/dl) & $9.28 \pm 1.80$ & $4.50 \pm 0.62$ & $4.23 \pm 0.66$ \\
Albumine (g/dl) & $4.58 \pm 0.34$ & $114.11 \pm 19.13$ & $131.99 \pm 41.28$ \\
ALT (units/l) & $140.59 \pm 19.51$ & $216.19 \pm 29.83$ & $197.38 \pm 79.15$ \\
AST (units/l) & $247.51 \pm 34.76$ & $0.47 \pm 0.05$ & $0.38 \pm 0.08$ \\
Creatinine (mg/dl) & $0.54 \pm 0.07$ & $126.0 \pm 20.61$ & $140.75 \pm 34.67$ \\
Cholesterol (mg/dl) & $109.17 \pm 29.72$ & $66.16 \pm 15.73$ & $59.66 \pm 12.56$ \\
Alkaline phosfatase (units/l) & $46.46 \pm 16.80$ & $117.98 \pm 18.59$ & $123.63 \pm 12.45$ \\
Glucose (mg/dl) & $133.43 \pm 17.29$ & $55.38 \pm 6.43$ & $49.18 \pm 6.29$ \\
Urea (mg/dl) & $57.93 \pm 10.99$ &
\end{tabular}

Data are expressed as mean \pm S.D., $\mathrm{n}=8$. No statistical difference between control and Ierobina ${ }^{\circledR}$ groups $(\mathrm{p}<0.05)$.

was observed for the treated animals as compared to the control group, for both males and females, only in the first week of Ierobina ${ }^{\circledR}$ administration. This effect was probably produced by the alcohol present in the formulation and it was reversed in the second week. Water is an essential nutrient due to its physicalchemical properties. Both dehydration and excessive hydration may cause serious health problems (Iversen and Nicolaysen, 2003). Dehydration of as little as 2\% loss of body weight results in impaired physiological and performance responses. Several factors may increase the likelihood of chronic and mild dehydration, including common consumption of alcohol. (Sluyter et al., 2000). Hence, in spite of the presence of alcohol in Ierobina ${ }^{\circledR}$, the water consumption was not affected in the chronic treated animals, a crucial condition for maintaining the organic equilibrium during the therapy with this product.

After killing the animals, the blood was taken for hematological and biochemical assays and selected organs (heart, liver, pancreas, kidney, lungs, stomach, spleen and testicles or ovarian) were dissected out for macroscopic and histological analysis. The hematological parameters of both male and female treated rats did not differ significantly from the control group. Confirming these results, histopathological evaluation of the organs collected from treated animals showed normal architecture as compared to the control group, indicating no detrimental changes and morphological disturbances resulting from the chronic administration of Ierobina ${ }^{\circledR}$ for 180 days. Lung alterations such as intra-alveolar hemorrhage, alveolar collapse, pulmonary congestion, among others, are commonly observed after chronic administration of drugs by gavage (Carlini et al., 1988; Palmeiro et al., 2003); however, it was not found in the present study.

Concerning the assayed biochemical parameters, no alteration was observed in comparison to the control group, including transaminases (AST and ALT), good indicators of liver function. Alterations on AST and ALT levels may indicate changes on cellular permeability or cellular injury and necrosis (Kaneko et al., 1997). The evaluation of such parameters is crucial, once reports on herbal toxicity have increased, resulting from the widespread use of herbal products, especially in developed countries (Stedman, 2002; Teschke et al., 2003). The integrity of hepatic function was evaluated by histopathological analysis of liver. Our analysis did not show any sign of histological damage on these organs that could be associated to hepatotoxicity reactions.

In addition, the evaluation of renal function is equally important, given that various renal syndromes have been reported after the use of medicinal plants, including tubular necrosis, acute interstitial nephritis, Fanconi's syndrome, hypokalemia or hyperkalemia, hypertension, papillary necrosis, chronic interstitial nephritis, nephrolithiasis, urinary retention, and cancer of the urinary tract (Isnard Bagnis et al., 2004). On the other hand, plant extracts have been used to prevent nefrotoxicity induced by gentamicin.

In the present work, both the increase in creatinine and accumulation of urea were not observed, 
which are relevant indicators for renal function impairment (Palani et al., 1999; Vidal et al., 2003) (Table 3). These results were also corroborated by kidney histopathological analysis, which indicated that chronic administration of Ierobina ${ }^{\circledR}$ devoid of nefrotoxicity.

In conclusion, Ierobina ${ }^{\circledR}$ can be considered safe at the oral doses tested, since it did not cause any death or adverse behavioral changes in the acute toxicity assay on mice and also in chronic studies on rats. The commercialization of this product in the Brazilian market for over 75 years, apparently without any notification of adverse effects, is another evidence that it devoid of toxicity. However, to confirm this hypothesis the clinical evaluation of Ierobina ${ }^{\circledR}$ must be undertaken.

\section{ACKNOWLEDGEMENTS}

This work was supported with a grant from CNPq (Brazil) (Projetos Fitoterápicos No. 52.1199/01.8) and with funds from Laboratório Belfar (Belo Horizonte, Brazil). $\mathrm{CNPq}$ is also acknowledged for a research fellowship (F.C.B.).

\section{REFERENCES}

Álvarez L, Gil AG, Ezpeleta O, Jalón-García, JA, López de Cerain A 2004. Immunotoxic effects of ochratoxin A in Wistar rats after oral administration. Food Chem Toxicol 42: 825-834.

Botion LM, Ferreira AVM, Côrtes SF, Lemos VS, Braga FC 2005. Effects of the Brazilian phytopharmaceutical product Ierobina ${ }^{\circledR}$ on lipid metabolism and intestinal tonus. J Ethnopharmacol 102: 137-142.

Braga FC, Valadares YM, Costa MA, Lombardi JA, Oliveira AB 2003. Estudo fitoquímico de Erythraea centaurium, Jacaranda caroba, Remijia ferruginea e Solanum paniculatum visando identificar marcadores químicos para o fitoterápico Ierobina ${ }^{\circledR}$. Rev Bras Farmacogn 13 (Supl.): 28-31.

Brasil 2004. Agência Nacional de Vigilância Sanitária. Resolução RDC nº 48 de 16 de março de 2004. Dispõe sobre o registro de medicamentos fitoterápicos. Diário Oficial da União, Brasília.

Carlini EA, Macaúbas CP, Oliveira MM, Barbosa VP 1988. Toxicologia pré-clínica da espinheirasanta (Maytenus ilicifolia). In: Brasil. Mistério da saúde, Central de Medicamentos. Estudo de ação antiúlcera gástrica de plantas brasileiras (Maytenus ilicifolia "espinheira-santa" e outras). S.I, Central de Medicamentos (Brasil), 49-66.

Carvalho ACB, Balbino EE, Maciel A, Perfeito JPS 2008. Situação do registro de medicamentos fitoterápicos no Brasil. Rev Bras Farmacogn 18: 314-319.

Da Silva J, Herrmann SM, Heuser V, Peres W, Marroni NP, González-Gallego J, Erdtmann B 2002. Evaluation of the genotoxic affect of rutin and quercetina by comet assay and micronucleus test. Food Chem Toxicol 40: 941-947.

Féres CA, Madalosso RC, Rocha OA, Leite JPV, Guimarães TMDP, Toledo VPP, Tagliati CA 2006. Acute and chronic toxicological studies of Dimorphandra mollis in experimental animals. $J$ Ethnopharmacol 108: 450-456.

Gesler WM 1992. Therapeutic landscapes: medical issues in light of the new cultural geography. Soc Sci Med 34: 735-746.

Gottlieb OR, Mors W 1980. Potential utilization of Brazilian wood extractives. J Agri Food Chem 28: 196-215.

Gundermann KJ, Godehardt E, Ulbrich M 2003. Efficacy of a herbal preparation in patients with functional dyspepsia: a meta-analysis of double-blind, randomized, clinical trials. Adv Therapy 20: 43-49.

Hasumura M, Yasuhara K, Tamura T, Imai T, Mitsumori $\mathrm{K}$, Hirose M 2004. Evaluation of the toxicity of enzimatically decomposed rutin with 13-weeks dietary administration to Wistar rats. Food Chem Toxicol 42: 439-444.

Hunt RH, Fallone C, Veldhuyzen Van Zanten S, Sherman P, Flook N, Smaill F, Thomson AB 2002. Etiology of dyspepsia: implications for empirical therapy. Can J Gastroenterol 16: 635-641.

Isnard Bagnis C, Deray G, Baumelou A, Le Quintrec M, Vanherweghem JL 2004. Herbs and the kidney. Am $J$ Kid Dis 44: 1-11.

Iversen PO, Nicolaysen G 2003. Water-for life. Tidsskrift Nors Laegef 123: 3402-3405.

Johannessen T, Petersen H, Kristensen P, Kleveland PM, Dybdahl J, Sandvik AK, Brenna E, Waldum H 1993. The intensity and variability of symptoms in dyspepsia. Scand J Primary Health Care 11: 50-55.

Kaneko JJ, Harvey JW, Bruss ML 1997. Clin Biochem Domestic Anim, 5th ed. Academic Press, San Diego, 932.

Lydeard S, Jones R 1989. Factors affecting the decision to consult with dyspepsia: comparison of consulters and non-consulters. J Royal Coll Gen Practitioners 39: 495-498.

Manoamani S, Vishwanathan VP, Subramanian S, Govindasamy S 1995. Biochemical studies on the antiulcerogenic activity of cauvery 100, an ayuverdic formulation in experimental ulcers. Ind J Pharmacol 27: 101-105.

Mittermeier R, AGil PR, Mittermeier C G 1997. Megadiversity: Earth's Biologically Wealthiest Nations. Mexico: CEMEX, Agrupación Sierra Madre.

OECD 1981. Guideline for Testing of Chemicals, Chronic Toxicity Studies $\mathrm{n}^{\mathrm{o}}$ 452, 1-14.

Palani V, Senthilkumaran RK, Govindasamy S 1999. Biochemical evaluation of antitumor effect of muthu marunthu (a herbal formulation) on experimental fibrosarcoma in rats. $J$ Ethnopharmacol 65: 257265.

Palmeiro NMS, Almeida CE, Ghedini PC, Goulart LS, Pereira MCF, Huber S, Silva JEP, Lopes S 2003. Oral subchronic toxicity of aqueous crude extract of Plantago australis leaves. $J$ Ethnopharmacol 88: 1518.

Philipson JD 1994. Natural products as drugs. Transactions of the Royal Society of Trop Med Hyg 1, S17-19.

Raza M, Al-Shabanah OA, El-Hadiyah TM, Al-Majed AA 2002. Effect of prolonged vigabatrin treatment on hematological and biochemical parameters in plasma, liver and kidney of Swiss albino mice. Sci Pharmac 70: 135-145. 
Saller R, Iten F, Reichling J 2001. Dyspeptic pain and phytotherapy - a review of traditional and modern herbal drugs. Forsch Komplementarmed Klass Naturheilkd 8: 263-273.

Saller R, Pfister-Hotz G, Iten F, Melzer J, Reichling J 2002. [Iberogast: a modern phytotherapeutic combined herbal drug for the treatment of functional disorders of the gastrointestinal tract (dyspepsia, irritable bowel syndrome)--from phytomedicine to "evidence based phytotherapy." A systematic review] Forsch Komplementarmed Klass Naturheilkd 9, Suppl., 1: $1-20$.

Sluyter F, Hof M, Ellenbroek BA, Degen SB, Cools AR 2000. Genetic, sex, and early environmental effects on the voluntary alcohol intake in Wistar rats. Pharmacol Biochem Behav 67: 801-808.

Stedman C 2002. Herbal hepatotoxicity. Semin Liver Dis 22: 195-206

Talley NJ, Zinsmeister AR, Schleck CD, Melton LJ 1992. Dyspepsia and dyspepsia subgroups: a populationbased study. Gastroenterology 102: 1259-1268.

Talley NJ 2001. Therapeutic options in nonulcer dyspepsia. $J$ Clin Gastroenterol 32: 286-293.

Teo S, Stirling D, Thomas S, Hoberman A, Kiorpes A, Khetani V 2002. A 90-day oral gavage toxicity study of D-methylphenidate and D,L-methylphenidate in Sprague Dawley rats. Toxicology 179: 183-196.

Teschke R, Gaus W, Loew D 2003. Kava extracts: safety and risks including rare hepatotoxicity. Phytomedicine 10: 440-446.

Thompson Coon J, Ernst E 2002. Systematic review: herbal medicinal products for non-ulcer dyspepsia. Aliment Pharmacol Ther 16: 1689-1699.

Tofovic SP, Jackson EK 1999. Effects of long-term caffeine consumption on renal function in spontaneously hypertensive heart failure prone rats. $J$ Cardiovasc Pharm 33: 360-366.

Vidal A, Fallarero A, Peña BR, Medina ME, Gra B, Rivera F, Gutierrez Y, Vuorela PM 2003. Studies on the toxicity of Punica granatum L. (Punicaceae) whole fruit extracts. J Ethnopharmacol 89:295-300. 